\title{
Bitlis Etnografya Müzesinde Bulunan Peşkirler Üzerine Bir Araştırma*
}

\section{A Research on the Peshkirs in the Bitlis Ethnography Museum}

\author{
Sultan Sökmen, ${ }^{\mathrm{a},{ }^{* *}}$ Betül Coşkun Çelik ${ }^{\mathrm{b}}$ \\ ${ }^{a}$ Dr. Öğr. Üyesi, Afyon Kocatepe Üniversitesi, Güzel Sanatlar Fakültesi, Geleneksel Sanatlar Bölümü, 03204, Afyon/Türkiye. \\ ORCID: 0000-0002-8838-0620 \\ b Dr. Öğr. Üyesi, Bitlis Eren Üniversitesi, Güzel Sanatlar Fakültesi, Geleneksel Türk Sanatları Bölümü, 13000, Bitlis/Türkiye. \\ ORCID: 0000-0002-6242-3485
}

\section{MAKALE BILLGİSI}

\section{Makale Geçmişi:}

Başvuru tarihi: 31 Temmuz 2017

Düzeltme tarihi: 07 Ocak 2018

Kabul tarihi: 03 Mart 2018

\section{Anahtar Kelimeler:}

Bitlis

Etnografya Müzesi

İşleme

Peşkir

Dokuma

\section{ARTICLE INFO}

\section{Article history:}

Received 31 July 2017

Received in revised form 07 January 2018

Accepted 03 March 2018

\section{Keywords:}

Bitlis

Ethnography Museum

Embroidery

Peskiras

Weave

\section{ÖZ}

Bu araştırmada, Bitlis Etnografya Müzesinde sergilenmekte olan bazı el işlemeli peşkirlerin teknik, renk, desen ve kompozisyon özelliklerinin incelenmesi amaçlanmıştır. Bu amaç doğrultusunda ilgili makamlardan gerekli izinler alınarak Bitlis Etnografya Müzesinde sergilenmekte olan yedi adet işlemeli peşkir incelenmiş ve envanter kayıtlarına bakılmıştır. Çalışmamızda, bu yedi peşkirin teknik, renk, desen ve kompozisyon özelliklerine yer verilmiștir. İncelenen envanter defterinde peşkirlerin sadece müzeye kazandırılma tarihi, boyutları ve peşkir hakkında kısa bilgilere rastlanmıştır. Çalışmada yer alan işlemeli peşkirlerde teknik olarak genellikle düz ve verev hesap iğnesi, verev pesent, verev sarma, düz sarma, balıksırtı ve gözeme işleme tekniklerinin kullanıldığı görülmüştür. Renklendirme olarak peşkirlerde çok renkli uygulamalar yapıldığı, en çok yeşil rengin kullanıldığı görülmüş̧ür. Motif ve kompozisyon olarak peşkirlerin hepsinde kısa kenarlara yerleştirilmiş bitkisel bezemelere rastlanmıştır.

\section{A B S T R A C T}

In this study, it is aimed to examine the technical, color, pattern and composition properties of some hand-made pendants displayed at Bitlis Ethnography Museum. For this purpose, necessary permits were taken from the relevant authorities, and the seven embroidered peshkirs and these inventory records exhibited at Bitlis Ethnography Museum were examined. In our work, these seven peshkirs' technical, color, pattern and composition features are included. In inventory records, only recorded time of peshkirs, their size and short information about them were found. In the embroidered peshkirs included in the study, it was observed that technically, generally flat and vertebrae calculus needle, verebe pesent, vertebral wrapping, flat wrapping, fishbone and eye treatment techniques were used. It was observed that many colors were applied in the peshkirs as the coloring and mostly green color was used. As a motif and composition, all of the peshkirs were found with herbal beads placed on short edges.

\section{Giriş}

Bugün ülkemizde önemli bir sanayi dalı olarak önemini korumakta olan dokumacılığın Osmanlı Devletinden Orta Asya'ya kadar uzanan köklü bir geleneği bulunmaktadır. Dokuma sanatı, kullanılan malzemeler, uygulanan teknik ve motif zenginlikleriyle Anadolu kültürünün zenginliğini yansitır. Anadolu'da her il kendine özgü gelenek görenekleri, eserleri ve el sanatları ile anılmaktadır. Bitlis, Geleneksel Türk El Sanatlarından dokumacılık ve işlemecilik bakımından zengin örneklere sahip olan illerimizden birisidir. Hemen hemen her evde bazı el

\footnotetext{
* Bu çalışma, Bitlis Valiliği İl Kültür ve Turizm Müdürlüğü Ahlat Müze Müdürlüğü’nün 24.05.2016 tarih ve 41544089-155.01/345 sayıll izni kapsamında hazırlanmıștır. Katkılarından dolayı müze çalıșanlarına teșekkür ederim. Peşkirlerin ișleme tekniklerinin yorumlanmasında yardımcı olan Begül Özkoca'ya ayrıca müteşekkirim.

** Sorumlu yazar/Corresponding author.

e-posta: sultan.sokmen@hotmail.com
} 
işlemeli örneklere rastlamak mümkündür. Ancak bu işleme örneklerinden peşkirler artık günlük hayatta kullanım geçerliliğini yitirmiştir. Peşkirlere halk arasında rastlamak oldukça zorlaşmıştır.

Peşkir, Türk Dil Kurumu Güncel Türkçe Sözlüğünde; "genellikle pamuk ipliğinden dokunmuş ince havlu, yemek yerken kullanılan, el kurulanan, büyük mendil biçiminde pamuk veya keten bez, peçete" şeklinde tanımlanmıştır (TDK, 2017). Peşkir, elleri, yüzü yıkadıktan sonra kurulamak için hazırlanmış, iki dar ucu bordürle bezenmiş, keten ya da pamuklu dokumadan yapılmış, dikdörtgen örtülerdir. Aynı zamanda peçete gibi dize örterek de kullanıldığı bilinmektedir (Barışta, 1999: 222). Saçaklı türleri de bulunan peşkirler, sırma, renkli ibrişim ve ipliklerle gergeflerde işlenmiştir. Topkapı Sarayında örnekleri bulunan "saray peşkirleri" daha çok süslüdür (Önder, 1995: 158).

Elde dokunmuş kumaşlar üzerine iki ucu işlemeli, yüzün yağını ve terini silmek amacıyla kullanılan peşkirlere Anadolu'da yağlık da denir. Anadolu' da bu peşkirler evlenme, doğum, askere gitme gibi güncel yaşamla ilgili olaylarda (hediye verme, hatırlama, gönül alma, önemseme düğün davetlerinde önem vererek çağırma anlamında da) kullanılmıştır. Sofrada herkesin önüne peçete gibi konulan örnekleri olabildiği gibi, yalnızca süs öğesi olarak kuşak kıvrımına sokularak taşınan örnekleri de mevcuttur (Özüdoğru, 1996: 161).

Osmanlı İmparatorluğu Dönemi’nde peşkirler, genellikle yemek peçetesi kullanım alanı ile ön plandadır (Sözen ve Tanyeli, 1996: 189). Düğünlerde, bayramlarda ve kalabalık aile sofralarına oturanların önüne on iki veya yirmi dört kişilik "dolak" adı verilen peşkirler dolanırdı. Peşkirlerin günlerce süren düğün törenlerinde görev alan kişilere armağan edildiği, kız evinin düğün davetiyesi olarak peşkir (okuntu) gönderdiği, çeyize süslü peşkirler serildiği, gelinin eşinin akrabalarına yaptığı nezaket ziyaretinde hediye bohçasına peşkir koyduğu, yeni gelin, yeni güvey ve genç çiftler için özel olarak ömür boyu beraberliklerin devamını simgeleyen çift kişilik gelin-güvey peşkiri dokunduğu belirtilmektedir (Tansuğ, 2003: 85-86). Bu kadar geniş bir kullanım alanı olan peşkirleri gerek dokuyucular gerekse işleme yapanlar büyük bir özveriyle süslemişlerdir. Dokuyucular dokumayı yaparken peşkiri kendinden desenli olarak dokuyabilirken, işleme yapanlarda dokunan peşkirleri farklı işleme teknikleriyle, rengârenk ipliklerle işleyerek süsleyebilmektedirler.

Tekstil süsleme dalları içinden en yaygın olanı "İşleme" dir. Anadolu insanı eski çağlardan beri giyim başta olmak üzere birçok kullanım eşyasını işleme sanatıyla süslemiştir. İşleme, dokumacılık (tekstil) alanındaki çeşitli bezeme teknikleri arasında iğne ya da tığla, beyaz ve renkli iplik, ipek iplik ve altın, gümüş teller ve iplikler kullanılarak yün, keten, pamuk ya da ipekten yapılmış beyaz, renkli, kalın ve ince kumaşlar, bazen de deri üzerine yapılan ve çeşitli özellikleri bulunan bir süsleme sanatı dalıdır (Sürür, 1976: 7).

İşleme yapımında iğne ve tığ kullanılır. Suzeni ve Zincir tekniğiyle yapılan işlemeler yalnız kasnakta, kasnak işi iğne ile ve süzeniler tığla, öteki işlemeler gergefte iğneyle işlenir. Ancak hesap işleri genellikle bez ayağı (tafta) dokuması tekniğiyle seyrek dokunmuş kumaşlara uygulanır (Sürür, 1976: 7). Barışta (1984) işlemeyi; ipek, yün, keten, pamuk, metal vb. iplikler kullanarak, çeşitli iğneler ve uygulama biçimleri aracılığıyla; keçe, deri, dokuma çeşitlemeleri vb. üzerine yapılan bezemeler olarak tanımlamıştır (Barışta, 1984: 1).

İşlemeler genellikle dokuma bez, keten, ipekli, kadife gibi tekstil yüzeyine yapılır. Türk işlemelerinde gül, lale, karanfil, kıvrık dal, meyve, yaprak, ağaç gibi bitkisel motiflerin yanı sıra insan ve hayvan gibi figürlü motifler, dikdörtgen, daire, zikzak, üçgen gibi geometrik motifler, yıldız ve saksı gibi nesneli motifler ve yazılı motifler görülmektedir. $\mathrm{Bu}$ nedenle işlemeli peşkirler Türk adet ve geleneklerinin simgesi niteliğindedir.

Sürür (1976), işlemeleri hesap işleri ve yazma işlemeler gibi çeşitlere ayırmış, hesap işlerinde kullanılan teknikleri; düz iğne, verev iğne, Türk işi, muşabbak, mürver, susma, kesme, pesent, civan kaşı, renkli sarma, sarmalı hesap, atma işi, tepebaşı, tel kırma, ince iş, antika adı altında, yazma işlemeleri; sarma işi, kasnak ve sûzeni, çin iğnesi, iğne ardı, balık kılçığı, balık sırtı, dival, zerdûz işi, aplikeler, benaluka, pulat-boncuk işi adı altında sınıflandırmıştır (Sürür, 1976: 36-44).

Bitlis ilinde işlemeli ürünler konusunda, bilimsel araştırma ve yayınların eksikliği dikkate alınarak, Bitlis Etnografya Müzesinde bulunan işlemeli peşkirler araştırma kapsamına alınmıştır. Bu çalışma ile Bitlis Etnografya müzesinde sergilenen işlemeli peşkirleri teknik, renk, desen ve kompozisyon özellikleri bakımından incelemek, bilimsel verilerle belgelemek ve tanıtmak amaçlanmıştır. Türk kültürünün önemli maddi ürünlerinden olan işlemeli peşkirler konusunda yapılan bu çalışma, kaybolmakta olan kültürel değerlerin tanıtılması, belgelenmesi ve bu konuda bilimsel çalışmalara katkıda bulunması açısından önem taşımaktadır.

\section{Bitlis Etnografya Müzesi}

13.09.2005 tarihinde hizmete açılan Bitlis Etnografya Müzesinde Bitlis'in yöresel kültürünü yansıtan (giyimkuşam, günlük kullanım eşyaları) eserlerin yanında el yazmaları ve Bitlis Kalesi kazılarından ele geçen ve müzeye getirilen eserlerin sergilendiği seksiyonlar bulunmaktadır. Müzede ağırlıklı olarak Roma, Bizans, Selçuklu ve Osmanlı dönemlerine ait eserler sergilenmektedir. Müze iki katlı olup, birinci katı aynı zamanda müzenin giriş katıdır. Bu bölümde, idari ofisler, depolar, mutfak ve lavabolar bulunmaktadır. Etnografik eserler müzenin ikinci katında sergilenmektedir. İkinci katta, halı ve kilimler, geleneksel giysiler, dokumacılıkta kullanılan tezgâhlar ve malzemeler, bastonculukta kullanilan malzemeler ve bastonlar, demircilikte kullanılan malzemeler ve demir eserler, çömlekler, el yazma eserler ve Bitlis Kalesi kazılarından çıkartılan eserlerin sergilendiği kısımlar bulunmaktadır. 
Resim 1. Bitlis Etnografya Müzesi

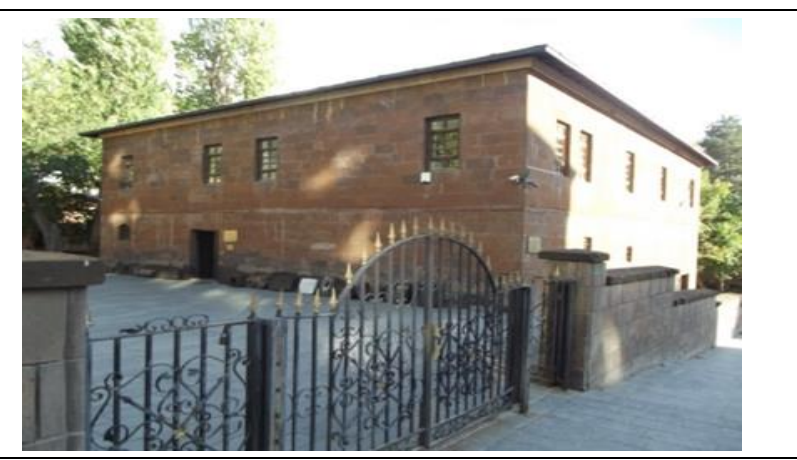

\section{Bulgular}

$\mathrm{Bu}$ çalışmada, Bitlis Etnografya Müzesinde vitrinlerinde sergilenmekte olan yedi adet peşkire yer verilmiştir. İncelenen peşkirler genel ve detay fotoğrafları, teknik, renk, desen ve kompozisyon özellikleriyle birlikte örnekler halinde verilmiştir.

Resim 2. 99 Envanter Numaralı Peşkirin Boydan Görünümü

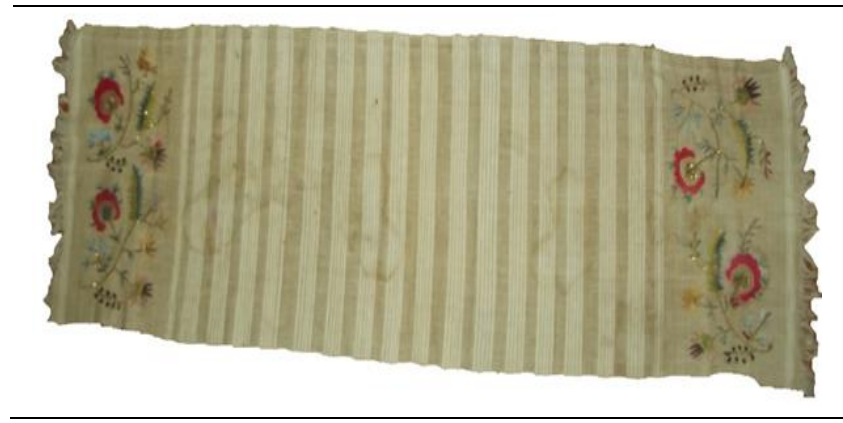

Resim 3. 99 Envanter Numaralı Peşkirin Detay Görünümü

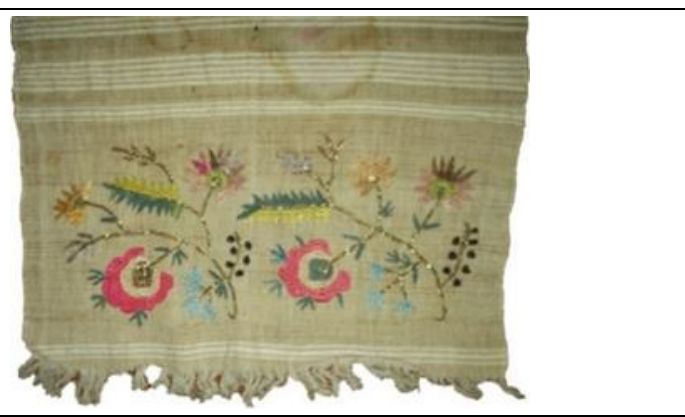

Resim 4. 99 Envanter Numaralı Peşkirin İşleme Detayı

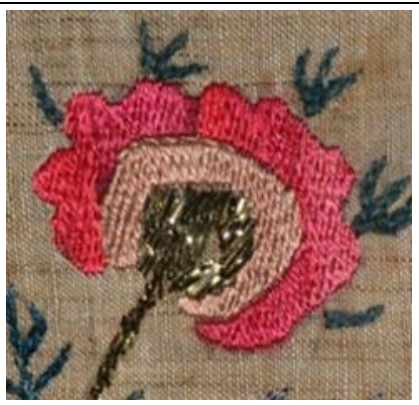

Örnek 1 (Resim 2, 3 ve 4): İncelenen ilk örnek 19.06.1971 tarihinde satın alma yoluyla müzeye kazandırılan 99 envanter numaralı peşkirdir. Peşkir 40x72 cm boyutlarında, dikdörtgen formundadır. Peşkirin zemini pamuk iplikle bez ayağ1 tekniğiyle dokunmuş olup, kısa kenarında saçak bırakılmıștır. Zemin dokumasında atkı yönünde üçerli ve beşerli gruplar halinde paralel çizgiler bulunmaktadır. Motifler dokumanın her iki kısa kenarına iki tekrarlı yerleştirilmiştir. Desen kompozisyonu, bitkisel bezemelerden olan çiçek motiflerinin spiral şeklinde düzenlenmiş bir dal üzerine yerleştirilerek oluşturulmuştur. Çiçek ve yapraklar verev pesent, dallar verev sarma, çiçeğin meyvesi olduğu düşünülen siyah noktalar da düz sarma tekniği ile işlenmiştir. Dalların işlenmesinde altın renkli sırma tel kullanılmıştır. Peşkirin işlemesinde yavruağzı, kahverengi, siyah, mavi, açık yeşil, koyu yeşil ve gri iplikler kullanıldığ1 görülmektedir. Peşkir lekeli ve oldukça yıpranmış durumdadır.

Resim 5. 67 Envanter Numaralı Peşkirin Boydan Görünümü

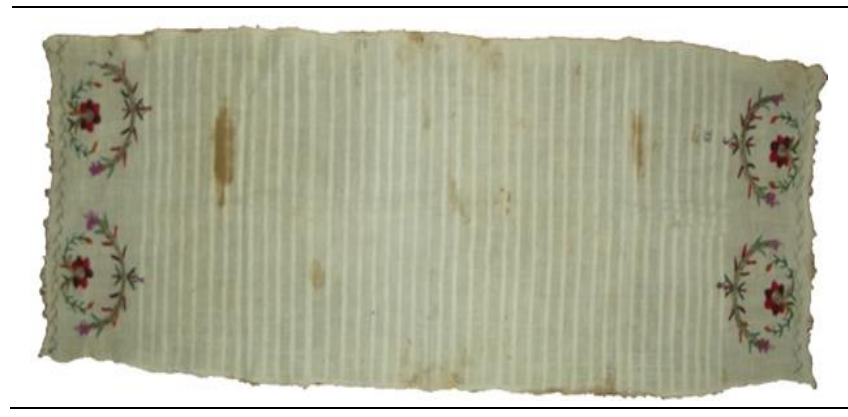

Resim 6. 67 Envanter Numaralı Peşkirin Detay Görünümü

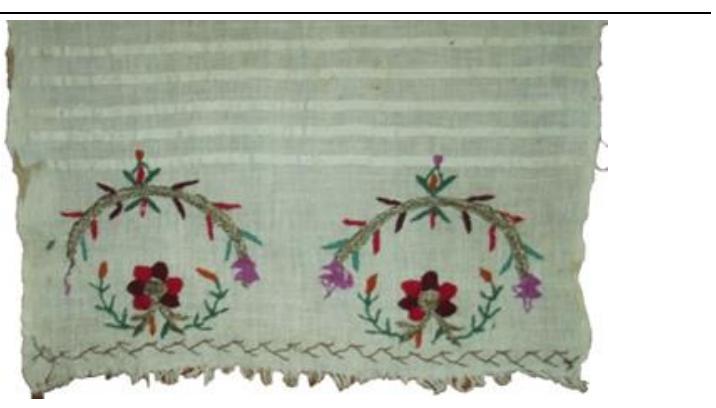

Resim 7. 67 Envanter Numaralı Peşkirin İşleme Detayı

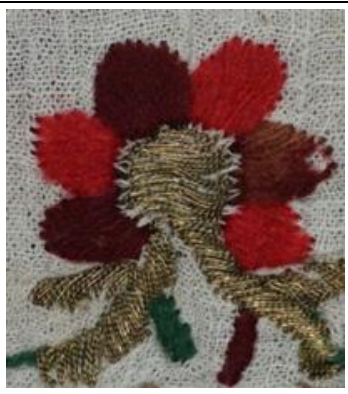

Örnek 2 (Resim: 5, 6 ve 7): İncelenen ikinci örnek 19.06.1971 tarihinde satın alma yoluyla müzeye kazandırılan 67 envanter numaralı peşkirdir. Peşkir 39x100 cm boyutlarında, dikdörtgen formundadır. Peşkirin zemini pamuk iplikle bez ayağı tekniğiyle dokunmuş olup, kısa kenarında saçak bırakılmıştır. Kazayağı motifiyle kenar suyu oluşturulmuştur. Zemin dokumasında atkı yönünde kalın paralel çizgiler bulunmaktadır. Motifler dokumanın her iki kısa kenarına iki tekrarlı yerleştirilmiştir. Bitkisel bezemelerden olan çiçek motifleri çanak şeklinde düzenlenmiş motifin üzerine yerleştirilerek desen kompozisyonu oluşturulmuştur. Çiçek göbekleri ve yapraklar düz sarma, çanak şeklinde olan motif balık sırtı, 
dallarda bulunan yapraklar sarma tekniğiyle ișlenmiștir. Çiçek göbekleri, çanak şeklindeki motif ve çiçek dalların bir kısmı altın renkli sim iplik ile işlenmiştir. Peşkirin işlemesinde kırmızı, yeşil, siyah ve pembe renkli ipliklerin kullanıldığı görülmektedir. Peșkirin günümüzdeki durumu lekelidir.

Resim 8. 77 Envanter Numaralı Peşkirin Boydan Görünümü

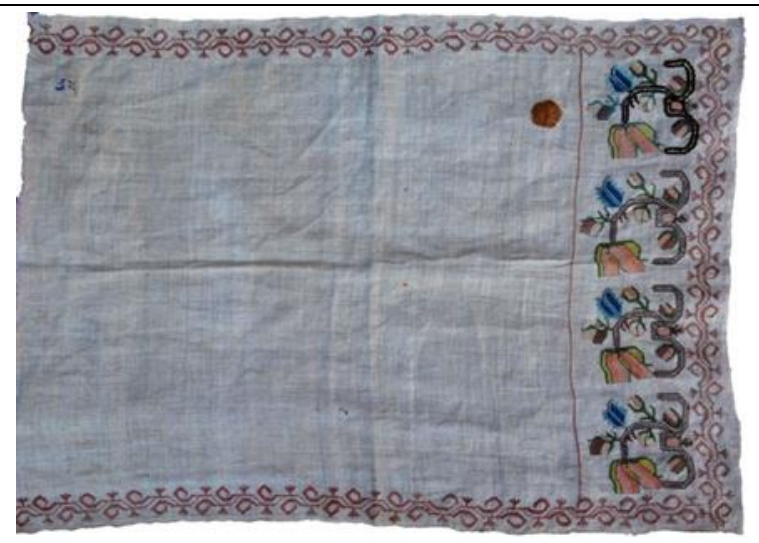

Resim 9. 77 Envanter Numaralı Peşkirin Detay Görünümü

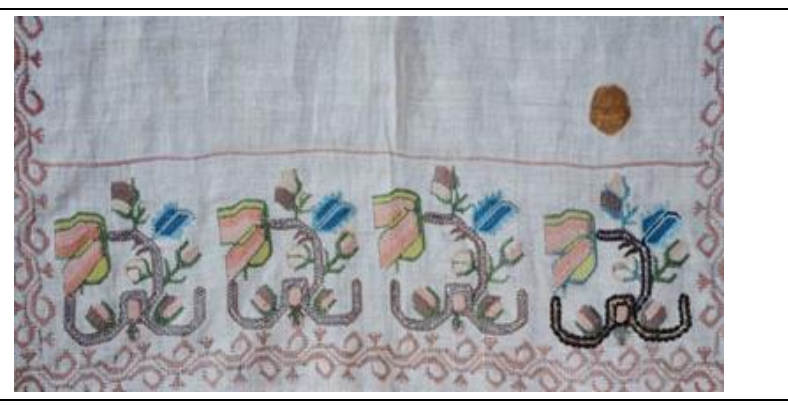

Resim 10. 77 Envanter Numaralı Peşkirin İşleme Detayı

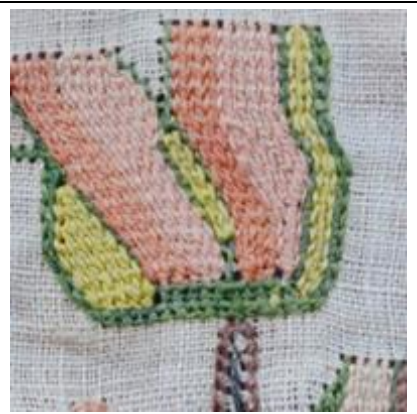

Örnek 3 (Resim: 8，9 ve10): Resim 8'de 77 envanter numaralı, 19.06.1971 tarihinde satın alma yoluyla müzeye kazandırılan peşkir parçası görülmektedir. Peşkir parça halinde olup, yarısı bulunmamaktadır. İncelenen peşkir parçası $45 \times 54 \mathrm{~cm}$ boyutlarında, dikdörtgen formunda, zemini pamuk iplikle bez ayağı tekniğiyle dokunmuştur. Motifler dokumanın kisa kenarına dört sıra halinde yerleştirilmiştir. Peşkirin desen kompozisyonuna bakıldığında, kısa kenarına bitkisel bezemelerden lale çiçeği motiflerinin işlendiği görülmektedir. Lale çiçekleri düz ve verev hesap iğnesi tekniği ile ipek iplik ile işlenmiştir. Lale çiçeği motifinin bir tanesinin dalının sırma telle, diğerlerinin pamuk iplikle verev sarma tekniği ile işlendiği görülmektedir. Peşkirin kısa ve uzun kenar suları düz ve verev hesap iğnesi tekniğiyle, lale çiçeklerinin altında bulunan düz çizgi ise çarpı iğne tekniği ile işlenmiştir.
Peşkirin işlemesinde açık mavi, koyu mavi, açık yeşil, koyu yeşil, kahverengi, siyah, yavruağzı renkli iplikler kullanılmıştır. Peşkirin günümüzdeki durumu lekelidir.

Resim 11. 81 Envanter Numaralı Peşkirin Boydan Görünümü

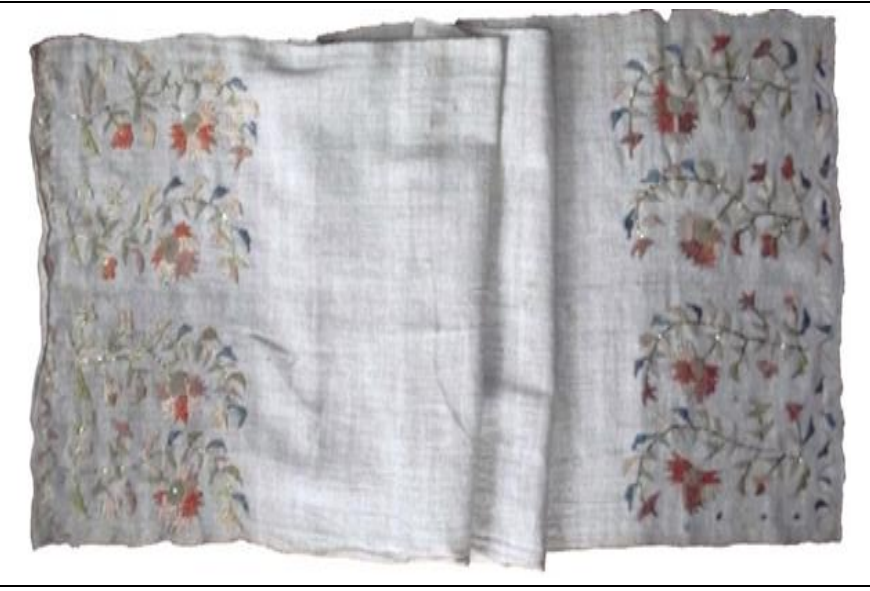

Resim 12. 81 Envanter Numaralı Peşkirin Detay Görünümü

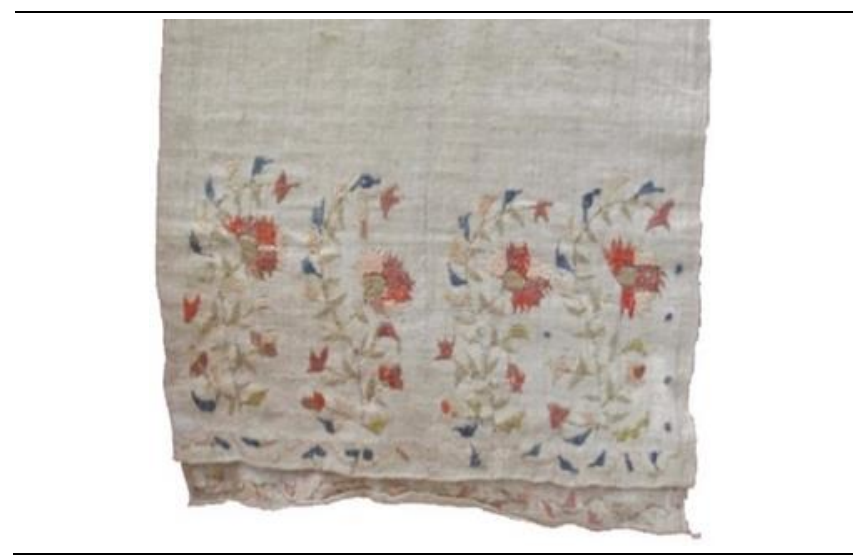

Resim 13. 81 Envanter Numaralı Peşkirin İşleme Detayı

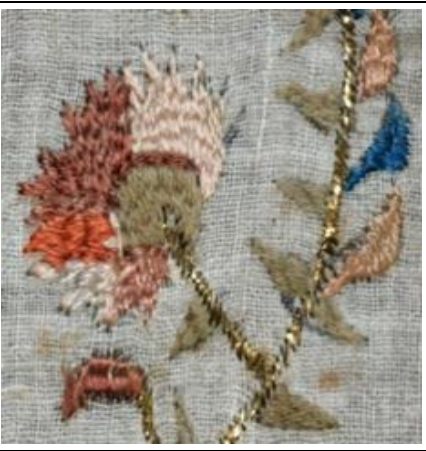

Örnek 4 (Resim 11, 12 ve 13): Resim 11'de 19.06.1971 tarihinde satın alma yoluyla müzeye kazandırılan 81 envanter numaralı peşkir görülmektedir. Peşkir 37x145 cm boyutlarında, dikdörtgen formundadır. Peşkirin zemini pamuk iplikle bez ayağı tekniğiyle dokunmuştur. Motifler dokumanın her iki kısa kenarına dört tekrarlı yerleştirilmişsir. Bitkisel bezemelerden olan çiçek motifleri ile desen kompozisyonu oluşturulmuştur. Çiçek göbekleri hasır iğne tekniği, çiçekler pesent hesap iğnesi tekniği, yapraklar ise sarma iğne tekniği ile pamuk iplikle işlenmiștir. Çiçeklerin dalları ise sırma tel ile işlenmiştir. Peşkirin işlemesinde mavi, kırmızı, yeşil, kahverengi, krem renkli ipliklerin kullanıldığı görülmektedir. 
Resim 14. 78 Envanter Numaralı Peşkirin Boydan Görünümü

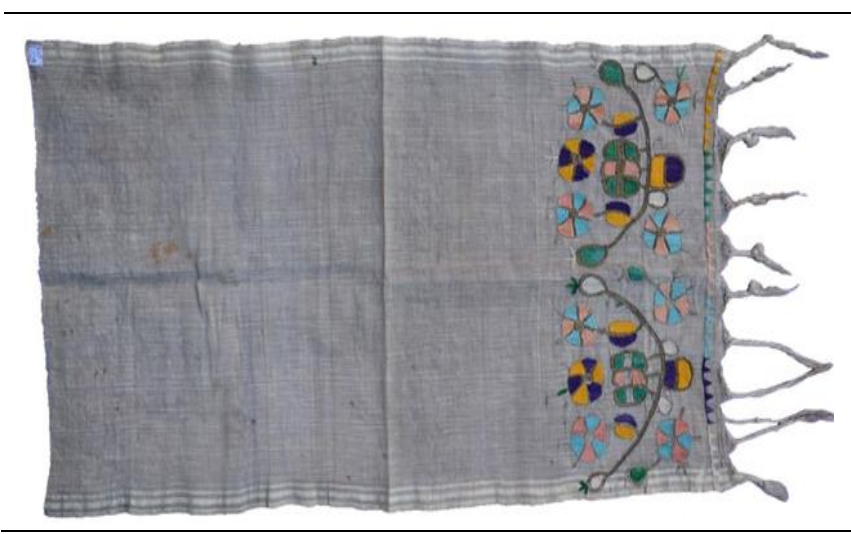

Resim 15. 78 Envanter Numaralı Peşkirin Detay Görünümü

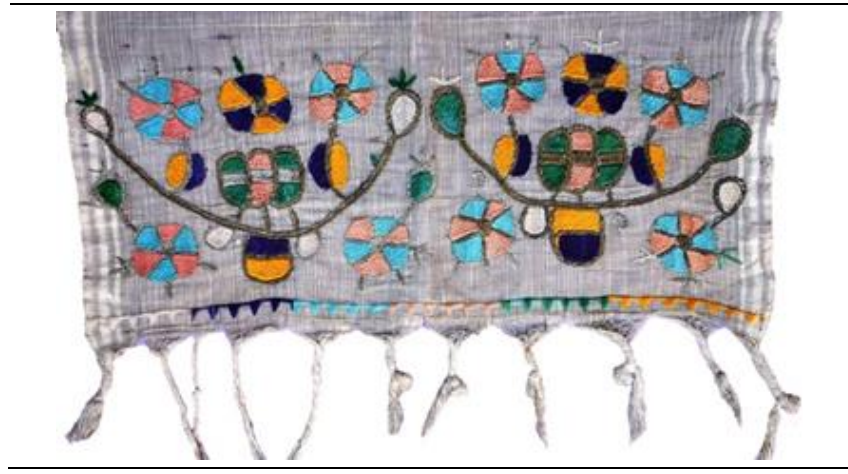

Resim 16. 78 Envanter Numaralı Peşkirin İşleme Detayı

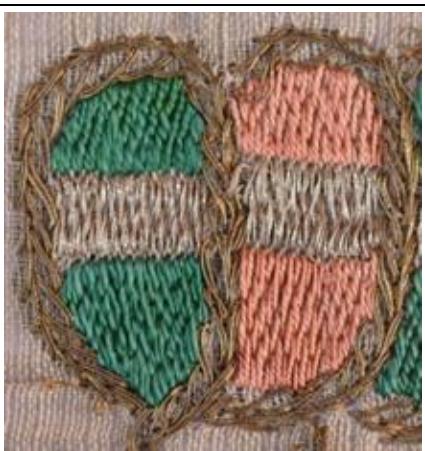

Örnek 5 (Resim 14, 15 ve 16): 44x74 cm boyutlarında, 19.06.1971 tarihinde satın alma yoluyla müzeye kazandırılan 78 envanter numaralı peşkirin zemini bez ayağı tekniğiyle, dikdörtgen formunda, pamuk iplikle dokunmuştur. Zemin dokumasının uzun kenarında çözgü yönünde üçer adet paralel çizgi bulunmaktadır. Dokumanın kenarlarının saçak bükme tekniği ile temizlendiği görülmektedir. Motifler dokumanın her iki kısa kenarına iki tekrarlı yerleştirilmiştir. Desen kompozisyonu, bitkisel bezemelerden olan nar motiflerinin çanak şeklinde düzenlenmiş bir motifin çevresine yerleştirilmesiyle oluşturulmuştur. Nar motifleri düz pesent, çanak şeklinde olan motiflerin kontürleri balıksırtı, motif içleri düz pesent, kenar suyu ise susma tekniği ile işlenmiştir. Çanak şeklinde olan motifin tamamı, nar motiflerinin bir bölümü gümüş renkli sim iplik ile işlenmiştir. Azda olsa motiflerin bazı kısımlarının altın renkli sim iplik ile işlendiği görülmektedir. Peşkirin işlemesinde açık mavi, mor, koyu sarı, yeşil, kırmızı, yavruağzı, beyaz renkli iplikler kullanılmıştır.
Resim 17. 100 Envanter Numaralı Peşkirin Boydan Görünümü

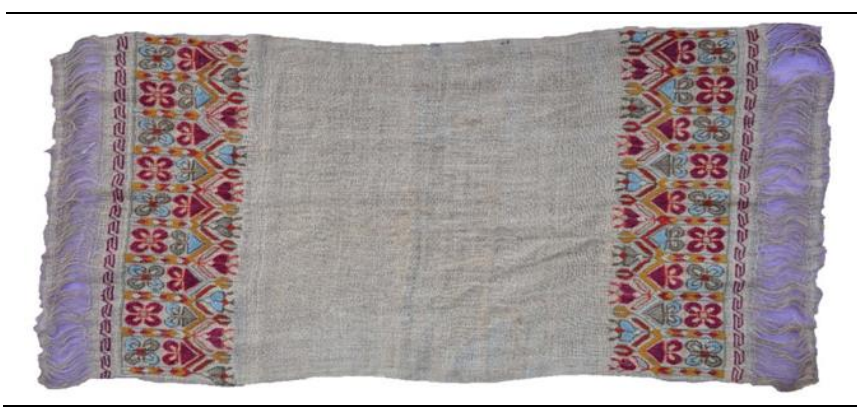

Resim 18. 100 Envanter Numaralı Peşkirin Detay Görünümü

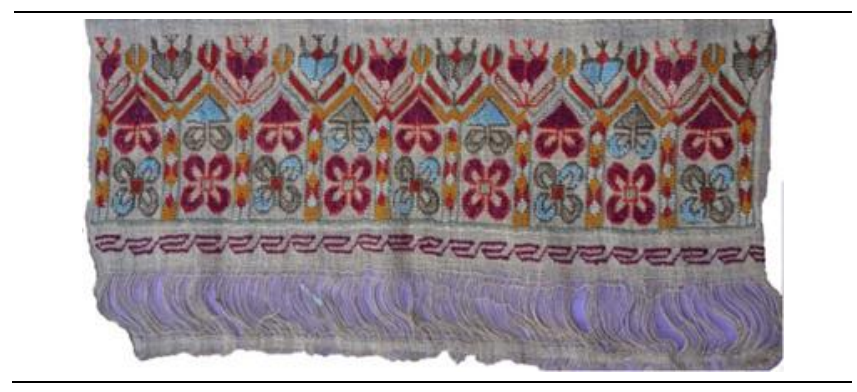

Resim 19. 100 Envanter Numaralı Peşkirin İşleme Detayı

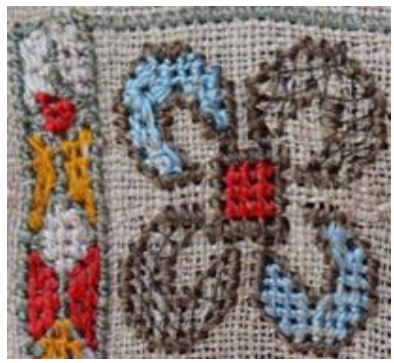

Örnek 6 (Resim 17, 18 ve 19): Zemini bez ayağ1 tekniğiyle, dikdörtgen formunda, pamuk iplikle dokunan 100 envanter numaralı peşkir incelenen altıncı örnektir. Dokumanın kısa kenarlarına $6 \mathrm{~cm}$ boyunda saçak bırakılmış olup atkı kaçırması nedeniyle saçaklar bozulmaya başlamıştır. 44x64 cm boyutlarında olan peşkir, 19.06.1971 tarihinde satın alma yoluyla müzeye kazandırılmıştır. Motifler dokumanın her iki kısa kenarına dokuz tekrarlı yerleştirilmiştir. Bitkisel bezemelerden olan çiçek motiflerinin yan yana sıralı olarak yerleştirilmesiyle desen kompozisyonu oluşturulmuştur. Motifler düz ve verev hesap iğnesi ve gözeme iğne teknikleriyle işlenmiştir. Peşkirin işlemesinde açık mavi, yeşil, kırmızı, turuncu ve beyaz renkli iplikler kullanılmıştır. Diğer örneklerin aksine işlemede sim iplik veya sırma tel kullanılmayan tek örnektir.

Resim 20. 97 Envanter Numaralı Peşkirin Boydan Görünümü

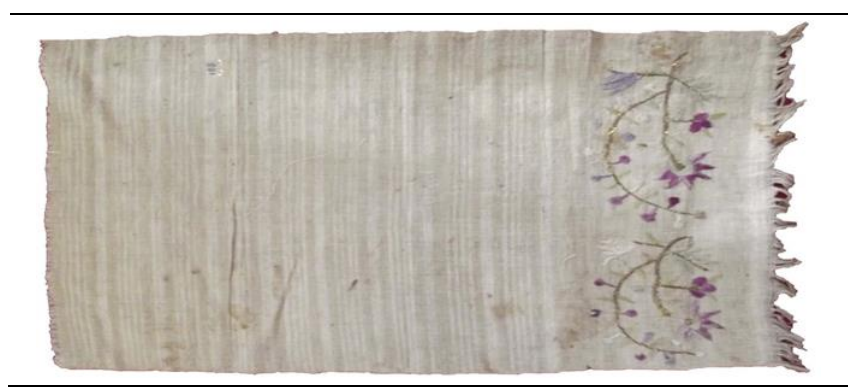


Resim 21. 97 Envanter Numaralı Peşkirin Detay Görünümü

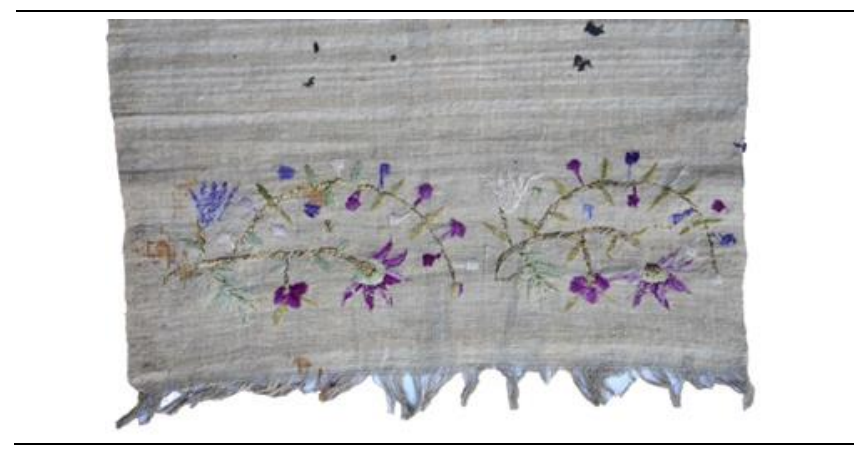

Resim 22. 97 Envanter Numaralı Peşkirin İşleme Detayı

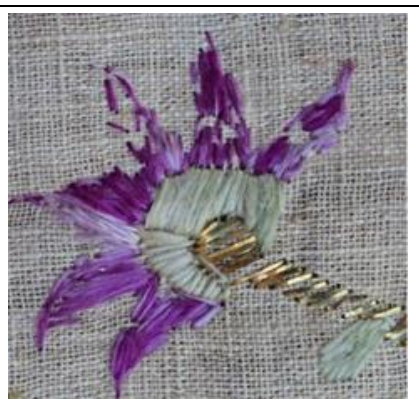

Örnek 7 (Resim 20, 21 ve 22): 97 envanter numaralı peşkir incelenen son örnektir. Parça halinde olup yarısı olmayan bu peşkir, satın alma yoluyla 19.06.1971 tarihinde müzeye kazandırılmıştır. İncelenen peşkir parçası $42 \times 58 \mathrm{~cm}$ boyutlarında, dikdörtgen formundadır. Peşkirin zemini pamuk iplikle bez ayağı tekniğinde dokunmuş, kısa kenarlara $3 \mathrm{~cm}$ boyunda saçak bırakılmıştır. Zeminde atkı yönünde birbirine paralel kalın ve ince çizgiler bulunmaktadır. Motifler dokumanın her iki kısa kenarına iki tekrarlı yerleştirilmiştir. Bitkisel bezemelerden olan çiçek motiflerinin düz bir dal, tomurcuk ve bazı yaprakların ise spiral şeklinde düzenlenmiş bir dal üzerine yerleştirilmesiyle desen kompozisyonu tamamlanmıştır. Dallar ve çiçek göbekleri altın renkli sırma tel ile verev sarma tekniği, yapraklar sarma tekniği, çiçek yaprakları tarama ve sarma tekniği ile pamuk iplikle işlenmiştir. Peşkirin işlemesinde mor, açık yeşil, eflatun, beyaz renkli ipliklerin kullanıldığ görülmektedir.

\section{Sonuç}

Osmanlı İmparatorluğundan bugüne kadar ulaşan peşkirler ve kullanımları ile ilgili literatür taraması yapıldığında, işlemeli peşkirlerin o dönemde sofra ve düğün geleneklerinin yanı sıra günlük kullanımda da çok işlevsel olduğu görülmektedir. Teknolojinin getirdiği değişiklikler, moda olgusu, endüstrileşme ve modern toplum yaşantısının yaygınlaşmasıyla birlikte işlemeli peşkirler yerini, kağıt peçetelere veya el havlularına bırakmışlardır. Anadolu'da işlemeli peşkir örneklerine halk arasında rastlamak oldukça zorlaşmıştır. İşlemeli peşkirlere genellikle müzelerde rastlamaktayı.

$\mathrm{Bu}$ çalışma kapsamında Bitlis Etnografya Müzesinde sergilenmekte olan yedi adet peşkir ve envanter defteri incelenmiş, incelenen peşkirlerin teknik, renk, desen ve kompozisyon özelliklerine yer verilmiştir. İncelenen envanter defterinde peşkirler hakkında detaylı bilgi verilmediği, sadece peşkirlerin müzeye kazandırılma tarihi, boyutları ve peşkir hakkında kısa bilgilere rastlanmıştır. Envanter defterinde peşkirlerin fotoğraflarına, nereden ve kimden alındığına dair bilgi bulunamamıştır. İncelenen peşkirlerin hepsinin zemin dokumasının bez ayağı tekniğiyle pamuk iplikle dokunduğu, beş örnekte saçak bırakıldığı, iki örnekte saçak bırakılmadan farklı kenar temizleme teknikleri kullanıldığ1 görülmüştür. Peşkirlerin hepsi dikdörtgen formda çeşitli en boy ölçüleri ile dokunmuştur. Bütün halde olan peşkirlerin en ve boy ölçüleri değerlendirildiğinde kısa kenar ölçüleri $37 \mathrm{~cm}$ ile $70 \mathrm{~cm}$ arasında, uzun kenarlar ölçüleri ise $64 \mathrm{~cm}$ ile $100 \mathrm{~cm}$ arasında değiştiği görülmektedir.

Çalışmada verilen yedi adet peşkir örneğinin bir tanesinde çiçek motiflerinin ipek iplikle, diğerlerinin pamuk iplikle işlendiği görülmüştür. İncelenen dört işleme örneğinde gümüş veya altın renkli sırma tel, ikisinde ise sim iplik kullanılmıştır. Peşkirlerde genellikle düz ve verev hesap iğnesi, verev pesent, verev sarma, düz sarma, balıksırtı ve gözeme işleme tekniklerinin kullanıldığı görülmektedir. Bunun haricinde hasır iğne ve susma teknikleri de kullanılmıştır. İşlemelerde kullanılan renklere baktığımızda en çok yeşil rengin kullanıldığı görülmektedir. Yeşilin ardından en çok kullanılan renkler kırmızı, yavruağZı, açık yeşil, açık mavi, mor, kahverengi ve siyahtır. Bunun haricinde beyaz, eflatun, gri, krem, koyu mavi, koyu sarı, pembe ve turuncu renkleri de tercih edilen diğer renklerdir. Zemin dokumasında kullanılan renk ekru olarak ifade edilen pamuk ipliğinin doğal rengidir. İncelenen peşkirlerin desen şemasında motiflerin dokumanın her iki kısa kenarına yerleştirildiği, desen kompozisyonunun ise tamamen bitkisel bezemelerden oluştuğu görülmektedir. İşleme desenlerinde genellikle çiçekler ve kıvrık dallarla motifler oluşturulmuştur. Peşkirlerin günümüzdeki durumuna baktığımızda birçoğunun yıpranmış, kirli ve lekeli olduğu, iki tanesinin parça halinde olduğu ve hiç birinin onarım görmediği göze çarpmaktadır.

Araştırma sonucunda, kültürümüzün korunması amacıyla Etnografya Müzesinde sergileme ve depolama konularında daha bilimsel ve ayrıntılı çalışma yapılması gerektiği, müzede yer alan peşkirlerin uzun yıllar boyunca çalışmalara 1şık tutması ve sonraki kuşaklara aktarılabilmesi için envanter bilgilerinin uzman kişilerce eksiksiz, anlaşılır bir dille tekrar yazılması, müzede mutlaka araştırmacılara yardımcı olabilecek ve müzeyi ziyaret edenleri bilgilendirebilecek bir etnolog ve tekstil uzmanının istihdam edilmesi gerektiği kanısına varılmıştır.

\section{Kaynakça}

Barışta, H. Ö. (1984). Türk Işsleme Sanatı Tarihi. Ankara. Gazi Üniversitesi Eğitim Fakültesi Yayınları.

Barıșta, H. Ö. (1999). Osmanlı Imparatorluğu Dönemi Türk İşlemeleri. Ankara: Kültür Bakanlığı Yayınları.

Önder, M. (1995). "Peşkir”, Antika ve Eski Eserler Kılavuzu. Ankara.

Özüdoğru, Ş. (1996) Silifke ve Sivrihisar Yörüklerinde Kilim, Peşkir ve Kuşak Örnekleri. Anadolu Sanat, 5, 156172. (Erişim: 31.07.2017), http://hdl.handle.net/11421/1017 
Sözen, M., \& Tanyeli, U. (1996). "Peşkir”, Sanat Kavram ve Terimleri Sözlüğü. İstanbul.

Sürür, A. (1976). Türk Işleme Sanatı. Türk Süsleme Sanatları Serisi: 4. İstanbul: Ak Yayınları.

Tansuğ, S. (2003). Dokumanın Hası Peşkir. Skylife, 22(239), 82-92.

TDK (2017). Türk Dil Kurumu Güncel Türkçe Sözlük. (Erişim: 31.07.2017), http://www.tdk.gov.tr/index .php?option=com_gts\&view $=$ gts 